\title{
Olive shootworm, Palpita persimilis Munroe (Insecta: Lepidoptera: Crambidae) ${ }^{1}$
}

\author{
James E. Hayden and Lyle J. Buss²
}

\section{Introduction}

Palpita persimilis Munroe (Lepidoptera: Crambidae) is a defoliator of olives and privet in South America (Gomez 1999; Chiaradia and Da Croce 2008). Examination of specimens submitted to UF-IFAS and FDACS-DPI prompted the discovery that the species has been established in Florida for many years, having been confused with two similar native species. The confusion parallels historical misidentifications in Peru (Gomez 1999). To date, all vouchered specimens in Florida with host information were found feeding on leaves of Ligustrum japonicum Thunb. (Japanese privet).

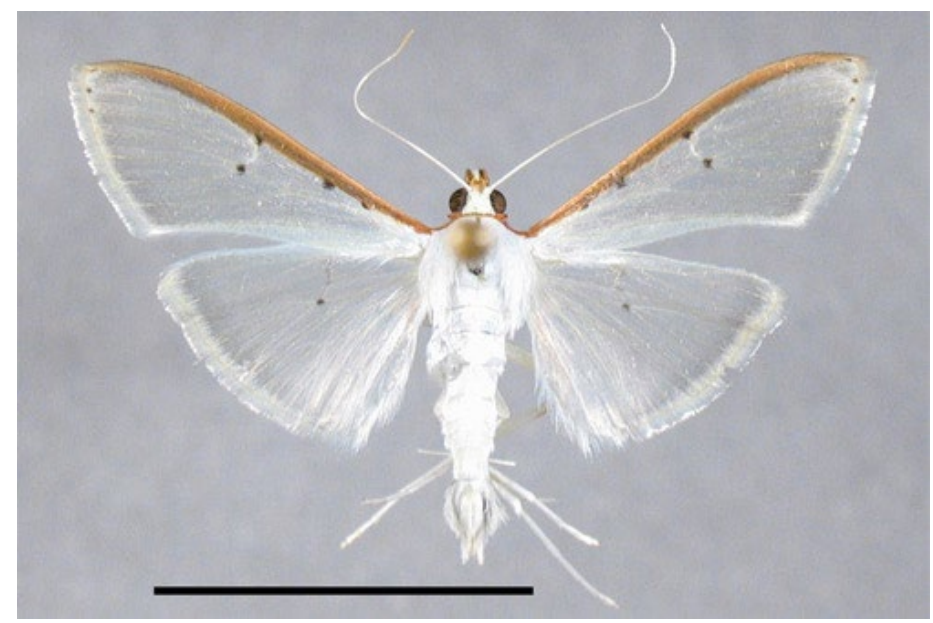

Figure 1. Palpita persimilis, adult habitus. Scale $=1 \mathrm{~cm}$.

Credits: James E. Hayden
Palpita Hübner includes several dozen tropical and temperate species globally, most of which feed on Oleaceae if the host is known. Palpita vitrealis (Rossi), better known by the synonym Palpita unionalis (Hübner), is a major pest of olive and jasmine in Europe and Asia (Yilmaz and Genç 2012). Palpita nigropunctalis (Bremer) in East Asia feeds on several oleaceous species, including ligustrum and lilac (Gotoh et al. 2011). The larvae commonly construct untidy webs of leaves and silk in which they consume the leaves and, in some species, also the fruit.

The initial detection in Florida was an infestation of ornamental privet trees in Sumter County in July 2012. The homeowner indicated that other infestations were

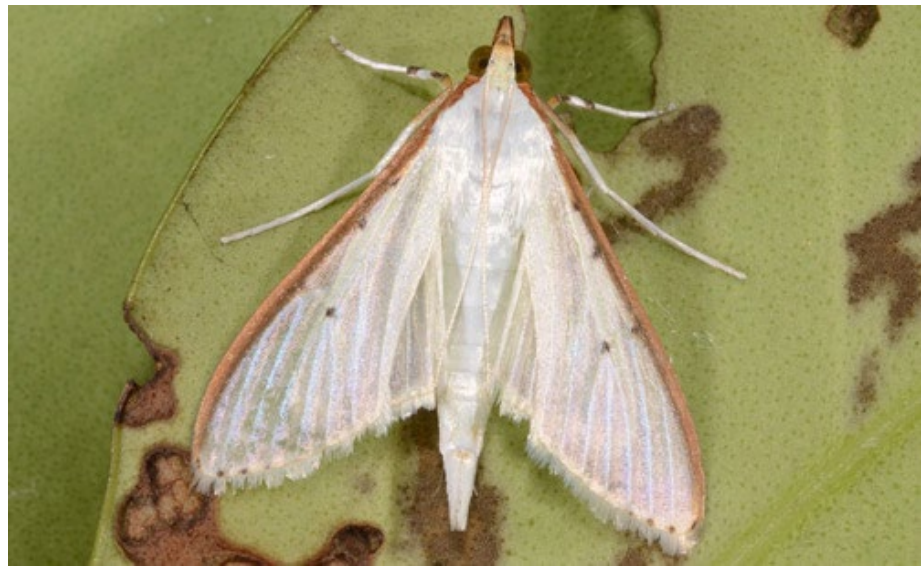

Figure 2. Palpita persimilis, live adult.

Credits: Lyle J. Buss

1. This document is EENY556, one of a series of the Entomology and Nematology Department, Florida Cooperative Extension Service, Institute of Food and Agricultural Sciences, University of Florida. Original publication date May 2013. Visit the EDIS website at http://edis.ifas.ufl.edu.

2. James Hayden, Florida Department of Agriculture and Consumer Services, Division of Plant Industry, and affiliate faculty, Department of Entomology and Nematology; and Lyle Buss, senior biological scientist; Department of Entomology and Nematology, Cooperative Extension Service, Institute of Food and Agricultural Sciences, University of Florida, Gainesville, FL 32611. 


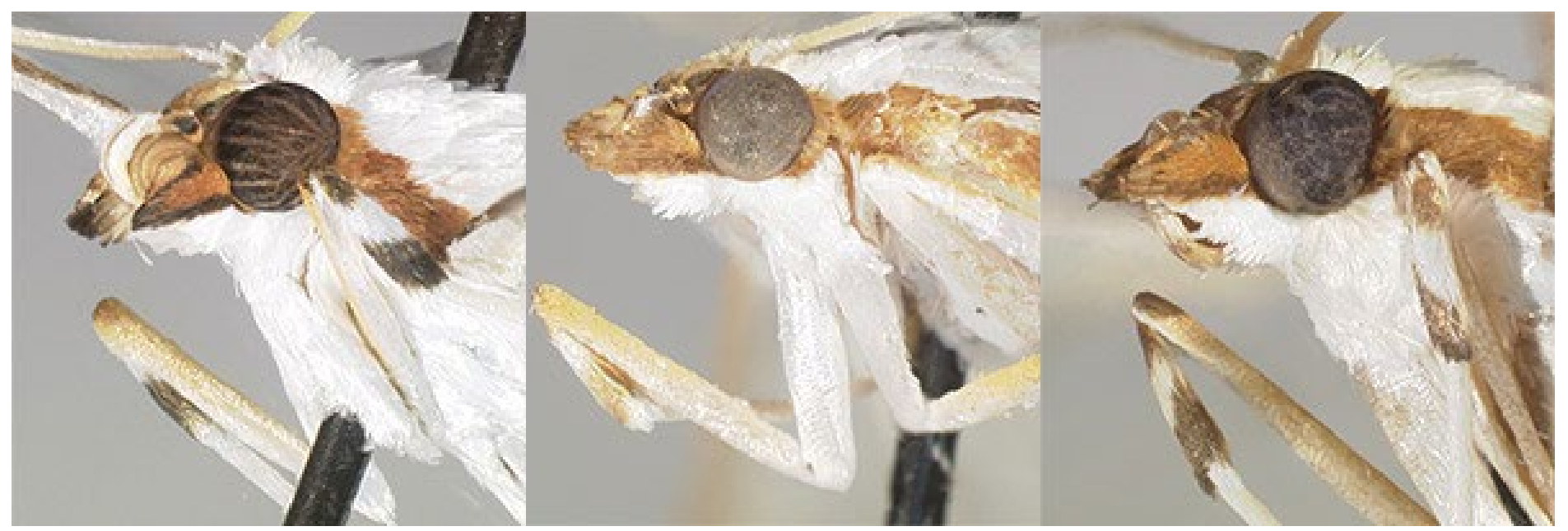

Figure 3. Labial palpi and foreleg tibia: A. Palpita persimilis; B. Palpita kimballi; C. Palpita quadristigmalis.

Credits: James E. Hayden

unreported in the area. More specimens were subsequently found in the Florida State Collection of Arthropods (FSCA), the earliest of which were raised on privet in January 1980 at the Fort Lauderdale IFAS Agricultural Research Center. Vouchered adults from 1992 (Valrico, FL) and 1999 (St. Cloud, FL) were raised from larvae feeding on privet in nurseries. Several lots of Palpita larvae that may represent the same species have been collected on privet since the early 1980s.

\section{Distribution}

The distribution includes southern Brazil, Bolivia (Sara Department), Peru, Costa Rica, northern Venezuela, Guadeloupe, Saint Kitts, the Dominican Republic, Haiti and Cuba (Munroe 1959; Alayo and Valdes Arteaga 1974; Gomez 1999; FSCA and MGCL specimens). Florida counties represented by vouchered adult specimens include Broward, Collier, Hillsborough, Miami-Dade, Monroe, Osceola and Sumter. The southern and central counties represent two centers of distribution. Geographically, the nearest population is in Cuba, where it was recorded on olive and privet (Alayo and Valdes Arteaga 1974). In addition, many lots of larval specimens of Palpita sp. were collected on privet in southeastern Florida counties in the early 1980s. Identification as Palpita persimilis cannot be confirmed without an adult specimen, but the sudden increase of infestations makes the identity plausible.

\section{Diagnosis}

The wingspan of observed specimens varies from 19 to 27 mm (Fig. 1). The almost entirely white wings are practically indistinguishable from those of two other Palpita species in Florida, Palpita kimballi Munroe and Palpita quadristigmalis (Guenée). However, the body size and aspects of coloration are useful for distinguishing Palpita persimilis.
The labial palpi (Fig. 3A) are mostly reddish brown with distinct dark-brown to black scales bordering the reddish area dorsally and ventrally; the same dark scales are also prominent on the maxillary palpi and lateral margin of the frons. The foreleg tibia (Fig. 3A) has distinctly black scales proximally and distally that contrast with the orange-brown femur. Palpita kimballi is the same size but lacks the black scales; the palpi are nearly uniformly reddish brown, with at most a few darker scales, and the foreleg tibia is orange-brown like the femur (Fig. 3B). Conversely, Palpita quadristigmalis has similar dark scales on the palpi and forelegs, although more brown or gray and not quite as distinct, but the average size is larger $(26-30 \mathrm{~mm}$ in FSCA specimens). The forewings also have a slightly yellowish tinge, although assessment requires direct comparison of the different species under good, consistent lighting. However, specimens of Palpita persimilis from the earliest interception (Broward Co.) are large and slightly yellow, like Palpita quadristigmalis, so definite identification requires genitalic dissection.

Two other species of related moths with white wings occur in the subtropical Nearctic. Palpita flegia (Cramer) is common in Florida, with a much larger wingspan (3.5-5.0 $\mathrm{cm})$ and a blue-gray forewing costa and white palpi. Palpita flegia is a conspicuous pest of yellow oleander (Thevetia peruviana (Pers.) K. Schum.). Diaphania costata (Fabricius) occurs in Texas, Oklahoma and the Caribbean, so it could occur in Florida as a rare stray. It averages $30 \mathrm{~mm}$ in wingspan, and it has an orange-brown forewing costa and orange palpi without black scales. Males have a tuft of hairs in a pocket underneath the forewing costa. Larvae of both species feed on Apocynaceae rather than Oleaceae and have the male antenna modified at the base with a mesally swollen scape and pedicel and a sinus onthe flagellum. The classification of both species is provisional, and they may be 
more closely related to Old World genera such as Stemorrhages Lederer.

Four more species of true Palpita are known in Florida: the widespread Palpita magniferalis (Walker), Palpita illibalis (Hübner), Palpita freemanalis Munroe in the Florida Panhandle, and Palpita maritima Sullivan and Solis (Sullivan and Solis 2013). There is little chance of confusing them, because the wings are mottled brown, gray and white, and the genitalia have symmetrical valve processes (Munroe 1952).

Male genitalia: Palpita persimilis has elongate processes on the valvae that curve around to parallel the distal margin of the valva (Fig. 4). Each process has two parts. The inner parts are symmetrical and have swollen, grooved apices. The outer parts are narrow and asymmetrical, with the right-hand one nearly as long as its inner part and slightly bifurcate, and the left-hand one half as long as its inner counterpart. Palpita quadristigmalis and Palpita kimballi have much shorter, crescent-shaped processes that are closer to the base of the valva and do not come close to paralleling the distal margin; they are symmetrical in the former species and asymmetrical in the latter.

Female genitalia: In Palpita persimilis (Fig. 5A), the lamella postvaginalis is slightly asymmetrical with respect to a spout-like mediodistal depression. The lamella is flat, rounded and symmetrical in the other white species in Florida (Fig. 5B, C).

Eggs: Females lay up to 200 eggs singly on the underside of leaves. The eggs are greenish yellow and $0.5 \mathrm{~mm}$ in diameter (Chiaradia and Da Croce 2008).

Larva: Characters used to diagnose larvae of Palpita persimilis from other Palpita species are not yet known. Live larvae are green with a pale yellow head and grow

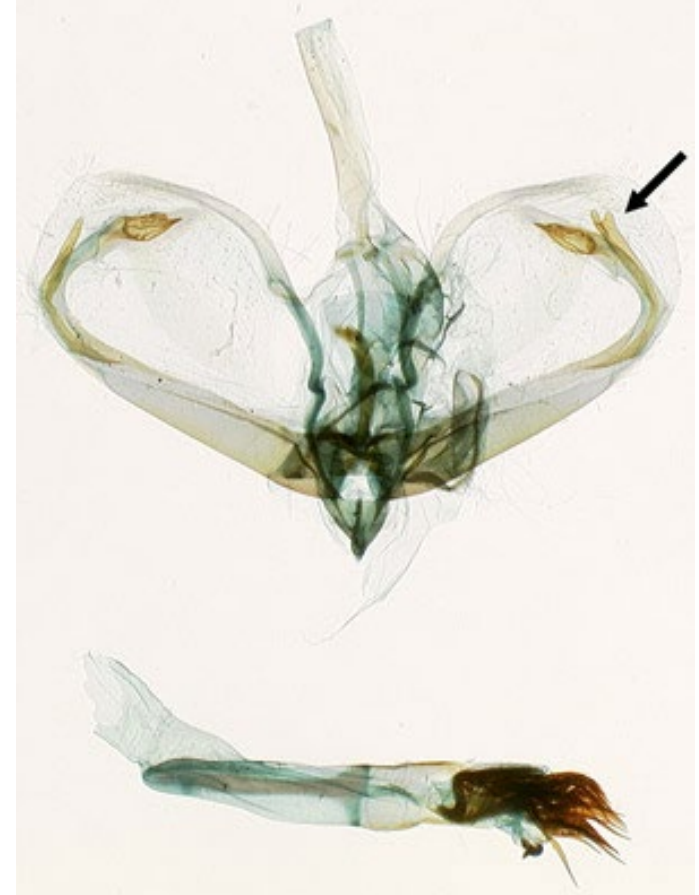

Figure 4. Male genitalia. Elongate processes of right valve indicated. Credits: James E. Hayden

to a length of about $2 \mathrm{~cm} \mathrm{(4/5} \mathrm{in.)} \mathrm{(Fig.} \mathrm{6).} \mathrm{Young} \mathrm{larvae}$ (Fig. 11) are similar to older stages. The prothoracic shield may be mottled to nearly colorless. The dorsal pinacula and the ventral margin of the subdorsal pinacula may or may not be pigmented dark brown; most other pinacula are not pigmented. When the pinacula are not otherwise colored, a distinct brown spot is obvious on the subdorsal pinaculum of the second thoracic segment (Fig. 7A). This last character also occurs in other Palpita species that feed on Oleaceae (Allyson 1984) as well as a few other crambid moths, such as the Bougainvillea caterpillar (Asciodes gordialis [Guenée]) and some specimens of the Mulberry leaftier (Glyphodes sibillalis Walker). The spot is obscured when other pinacula are colored (Fig. 7B).

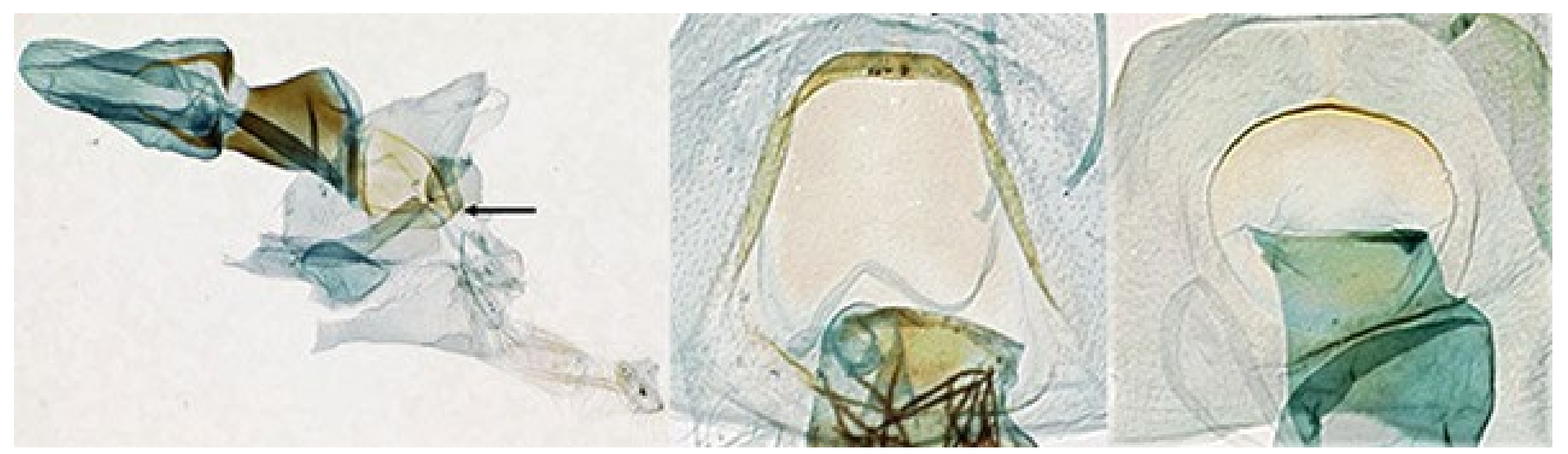

Figure 5. Female genitalia: A. Palpita persimilis, lamella postvaginalis indicated; B. lamella postvaginalis of Palpita kimballi; C. same, Palpita quadristigmalis.

Credits: James E. Hayden 


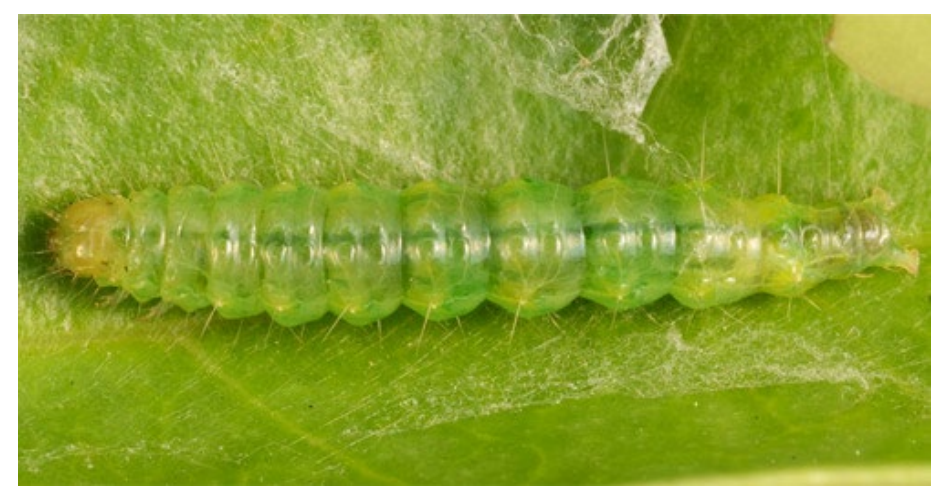

Figure 6. Live larva, about $2 \mathrm{~cm}$ long.

Credits: James E. Hayden

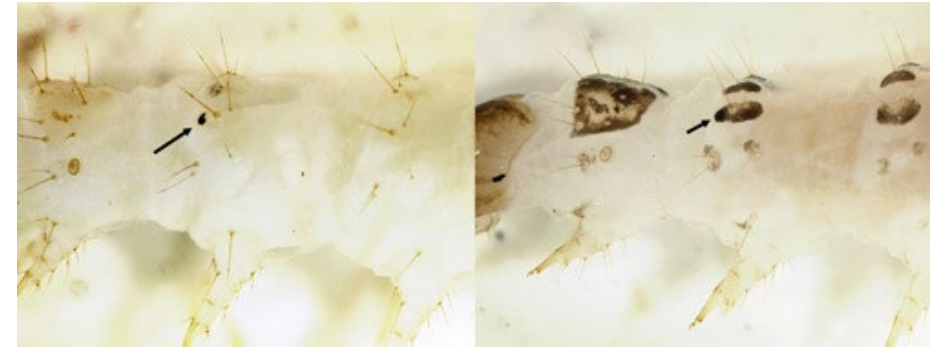

Figure 7. Detail of thoracic subdorsal pinacula: A. brown spot indicated on subdorsal pinaculum of second thoracic segment; $B$. pinaculum entirely melanized, obscuring the brown spot. Credits: James E. Hayden

Pupa: No diagnostic characters are known for the pupa.

\section{Key}

The following key applies to adults of white-winged Palpita and related species in Florida and nearby areas.

1. Wingspan 3.5-5.0 cm (1.4-2.0 in); forewing costa bluish gray; base of male antennal flagellum with hollow sinus; larva on Apocynaceae........ Palpita flegia

1'. Wingspan $3.0 \mathrm{~cm}$ (1.2 in) or less; forewing costa orangebrown; base of male antenna usually not modified; larva usually on Oleaceae, rarely Apocynaceae ....... 2

2(1'). Wing without spots, or with at most one spot on discal cell; male with base of antennal flagellum hollowed and scale-covered; tuft of hair in ventral pocket along male forewing costa; male valva with one small downturned clasper; female with ostium bursae unmodified and corpus bursae without signa (sclerites); larva on Apocynaceae .... .. Diaphania costata (possible stray from Caribbean)

2'. Forewing with one small black spot on central cell, two or three spots along costa, and two or three at margin of wing apex (Fig. 1-2); male antenna and base of wing never modified or tufted; male valva with two or three upturned claspers (Fig. 4); female with ostial plate (lamella postvaginalis, Fig. 5A-C), and corpus bursae with pair of large, horn-shaped signa (sclerites, Fig. 5A); larva on Oleaceae... ... Palpita spp. 3

3(2'). Forewing length $2.6-3.0 \mathrm{~cm}$ (1.0-1.2 in); palpi and foreleg tibia with brown-gray scales (in Florida population; Fig. 3C); male valva with three short, symmetrical claspers in crescent shape; lamella postvaginalis circular (Fig. 5C) . . ...... Palpita quadristigmalis

3'. Forewing length 1.9-2.7 cm (0.75-1.1 in); foreleg tibia orange or black; male valvae with asymmetrical claspers; female lamella postvaginalis longer than wide ..... 4

4(3'). Palpi and foreleg tibia orange (Fig. 3B); male with short, crescent-shaped claspers; lamella postvaginalis symmetrical and not tapered like a spout (Fig. 5B) ..... Palpita kimballi

4. Palps with black edges and foreleg tibia black (Fig. 3A); male with long claspers reaching near distal end of valva (Fig. 4); lamella postvaginalis asymmetrical, tapered like a spout (Fig. 5A) ...... Palpita persimilis

\section{Hosts}

Ligustrum japonicum Thunb. (Japanese privet) in Florida and elsewhere, and Olea europaea L. (olive) in southern and western South America (Wille 1952; Chiaradia and Da Croce 2008).

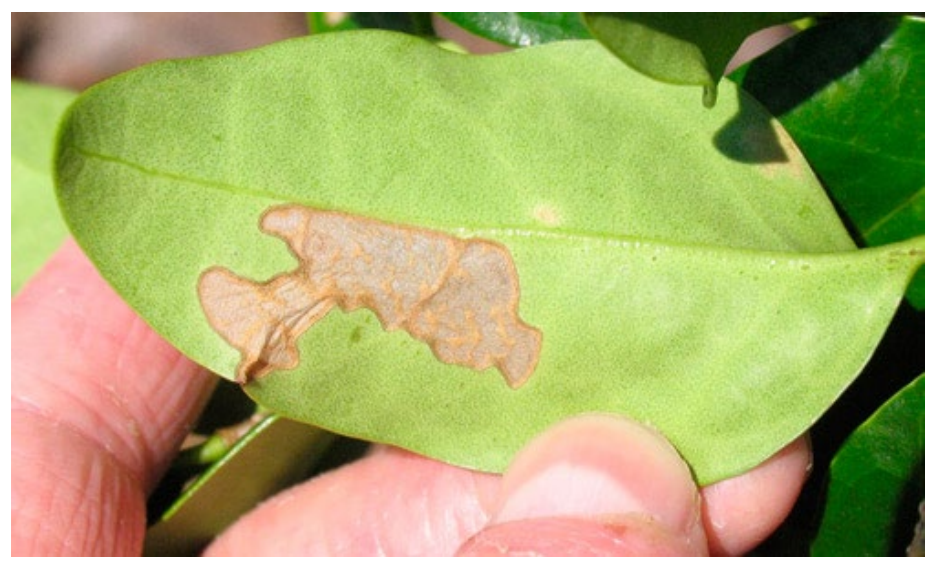

Figure 8. Feeding damage to epidermis of leaf. Credits: James E. Hayden 


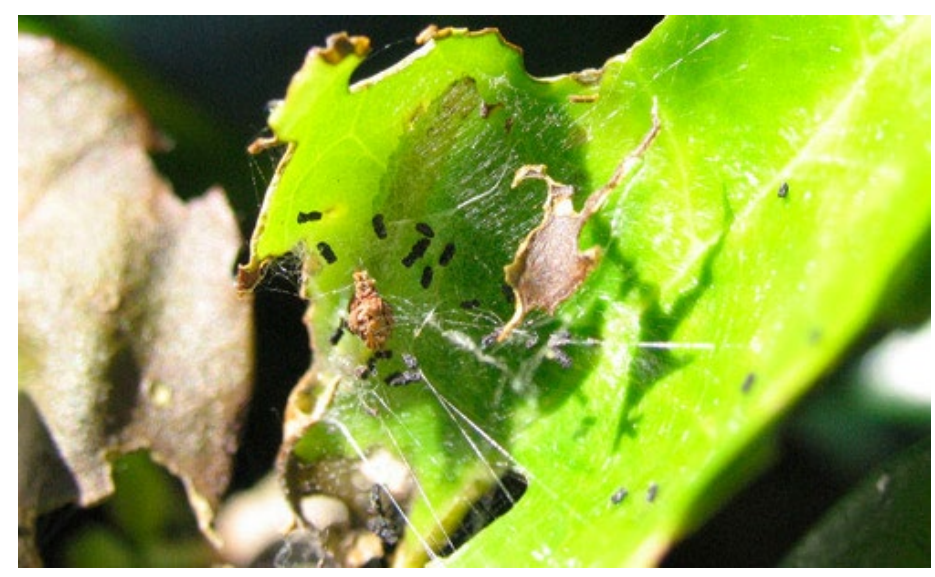

Figure 9. Leaves tied together with larva inside.

Credits: James E. Hayden

\section{Behavior}

Wille (1952) and Chiaradia and Da Croce (2008) describe larval behavior in South America. The number of days until egg hatch depends on temperature, ranging from 8 to 15 days. Early instar larvae consume buds and tender leaves, and later instars may eat older, harder leaves. They roll leaves into nests, stripping the surface or skeletonizing, and the buds and leaves dry up. They eat the olive fruits only rarely, and damage to flowers is not reported. The larval stage lasts 30 to 45 days. Pupation usually occurs in crevices in the bark and lasts 10 to 20 days. Total generation time is 50 days in spring to 65-80 days in winter. There may be five or six generations per year. Adults are active by day as well as night, but they are reclusive and hide under leaves of the host. Elevated temperatures (especially warm winters) and high precipitation and humidity favor population growth (Wille 1952; Chiaradia and Da Croce 2008). Observations of the species in Florida agree with the above. Larvae of all stages prefer young leaves and new growth, but not flowers. They feed primarily on the epidermis (Fig. 8), but older larvae can eat holes in larger leaves. They construct shapeless, frass-laden nests of leaves tied together with silk

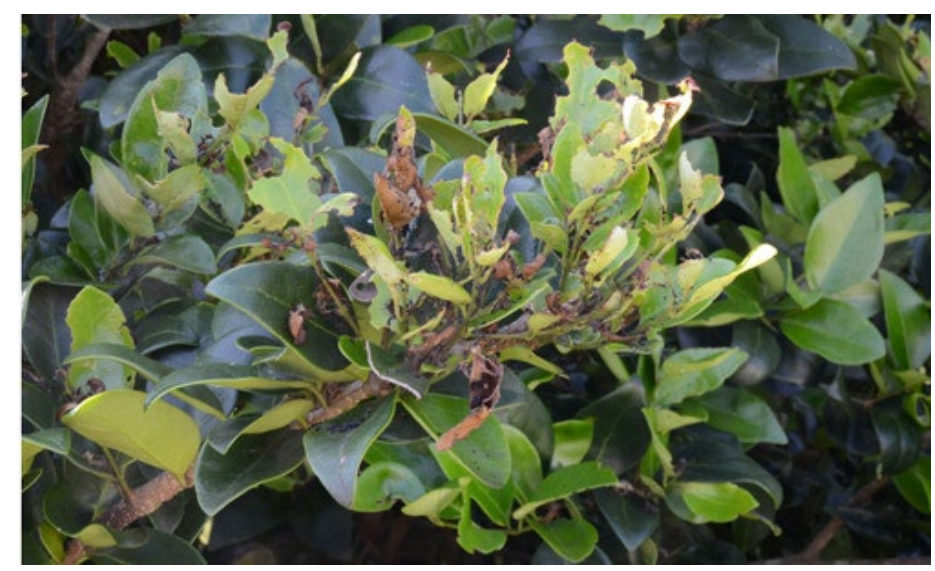

Figure 10. Defoliation of new growth. Credits: Lyle J. Buss
(Fig. 9). Damage can result in the curling of older leaves. In the primary observation in Sumter County, foliage was trimmed at the end of July to remove nests and eggs, but within five weeks, new flushes of leaves were supporting another large population (Fig. 10).

\section{Management}

Control measures are difficult because of the habit of concealed feeding. Several natural enemies have been tested with varying success (Chiaradia and Da Croce 2008). Trimming foliage to remove eggs and nests, if applied, should be done thoroughly, because any surviving larvae will prefer to consume the resulting new growth.

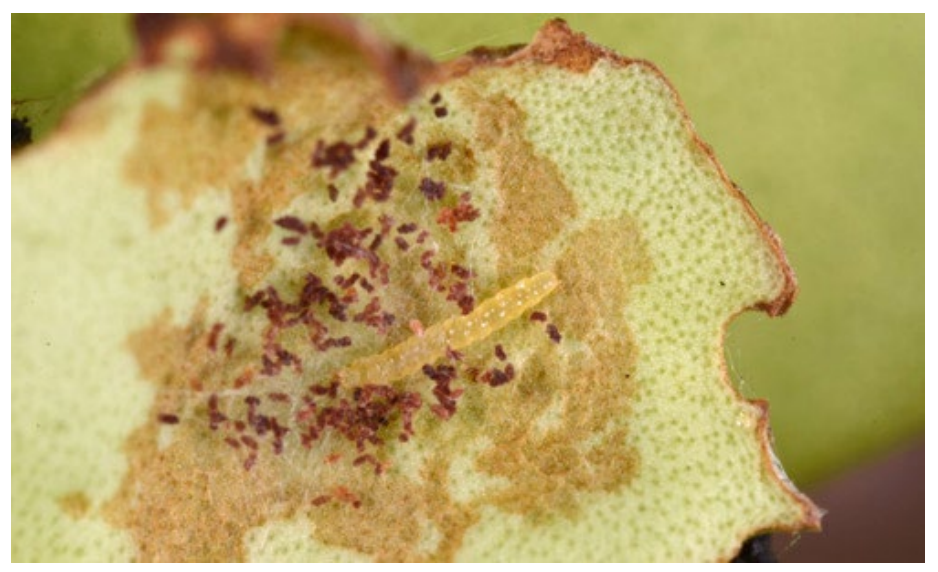

Figure 11. Young larva, about $2 \mathrm{~mm}$ long. Credits: Lyle J. Buss

\section{Acknowledgements}

We thank Dr. M. A. Solis (USDA-ARS) for confirming the identification and L. A. Chiaradia (Epagri/Cepaf, Santa Catarina, Brazil) for providing a copy of his important publication. Dr. J. B. Heppner (McGuire Center for Lepidoptera, Gainesville, FL) vouchered specimens in the FSCA. Dr. C. V. Covell, Jr. (McGuire Center), L. Somma, C. Whitehill, and Dr. W. Dixon (FDACS-DPI) provided many helpful comments and suggestions for the manuscript.

\section{Selected References}

- Alayo DP, Valdes Arteaga V. 1974 [1975]. Notas sobre Lepidópteros de Cuba. I. Poeyana 139: 1-11.

- Allyson S. 1984. Description of last-instar larvae of 22 species of North American Spilomelini (Lepidoptera: Pyralidae: Pyraustinae) with a key to species. The Canadian Entomologist 116: 1301-1334.

- Chiaradia LA, Da Croce DM. 2008. Caracterização, danos e manejo de pragas da oliveira. Agropecuaria Catarinense 21:53-55. 
- Gomez H. 1999. La verdadera identidad del "gusano del brote del olivo" en el Perú (Lepidoptera, Pyralidae). Revista Peruana de Entomologia 41: 19-22.

- Gotoh T, Hagino Y, Doke K. 2011. Life cycle of the lilac pyralid Palpita nigropunctalis (Bremer) (Lepidoptera: Crambidae) on five oleaceous tree species. Journal of Asia-Pacific Entomology 14: 195-200.

- Munroe EG. 1952. The illibalis group of the genus Palpita Hübner (Lepidoptera: Pyralidae). The Canadian Entomologist 84: 43-55.

- Munroe, EG. 1959. New species and a new subspecies of Palpita (Lepidoptera: Pyralidae). The Canadian Entomologist 91: 641-650.

- Sullivan, J.B. and M.A. Solis. 2013. A new species of Palpita (Crambidae, Spilomelinae) from the coastal plains of southeastern United States. ZooKeys 264:3-9.

- Wille JE. 1952. Entomología Agrícola del Perú (Ed. 2). Ministerio del Agricultura, Lima.

- Yilmaz Ç, Gençh. 2012. Determination of the life cycle of the Olive Fruit Leaf Moth, Palpita unionalis (Lepidoptera: Pyralidae) in the laboratory. Florida Entomologist 95:

162-170. 